\title{
PENDAPAT KORAN TEMPO TENTANG INDEPENDENSI KPK
}

\author{
Victor Andreas Simanjuntak, \\ Universitas Jayabaya, Jakarta \\ victorsim81@gmail.com
}

\begin{abstract}
The editorial serves as an opinion of the newspaper on issues or news that are interesting or controversial in society. With compact, clear and impartial writing, newspaper editorials can also serve as a guide for the reader in addressing a problem. Including the attitude of Koran Tempo in viewing the existence of Corruption Eradication Commission (KPK) which often get negative opinion from certain party. This research concludes Koran Tempo provides defense against KPK because this institution is needed to eradicate corruption
\end{abstract}

Keyword: Editorial, Newspaper, Corruption, KPK

\section{ABSTRAK}

Tajuk rencana berfungsi sebagai pendapat dari suratkabar terhadap persoalan atau berita yang menarik atau menjadi kontroversial di tengah masyarakat. Dengan penulisan yang ringkas, jernih dan tidak memihak, tajuk rencana suratkabar juga bisa menjadi pedoman bagi pembaca dalam menyikapi suatu masalah. Termasuk sikap Koran Tempo dalam melihat keberadaan Komisi Pemberantasan Korupsi (KPK) yang sering mendapatkan opini negatif dari pihak tertentu. Penelitian ini menyimpulkan Koran Tempo memberikan pembelaan terhadap KPK karena lembaga ini diperlukan untuk memberantas korupsi.

Kata kunci: Tajuk Rencana, Suratkabar, Korupsi, KPK

\section{Pendahuluan}

Pemberitaan media massa tentang suatu peristiwa atau kasus yang menjadi kebutuhan masyarakat merupakan informasi penting bagi khalayak.

Kemajuan teknologi di bidang komunikasi dan informasi telah merubah 
persepsi masyarakat akan pentingnya suatu berita atau informasi.

Proses penyampaian dan penerimaan pesan ke berbagai tempat hingga menembus batas suatu Negara kini semakin efektif dan efisien, bahkan luar angkasa sekalipun tak menjadi jarak dalam proses tersebut.

Setelah memasuki era kebebasan pers dan terlepas dari zaman kekeringan dalam arti kata "informasi", Negara Indonesia mengalami banyak kemajuan dalam penyebaran informasi melalui media massa. Dan kini pers Indonesia bisa menjalankan peran dan fungsinya dengan baik.

Di era kebebasan pers sekarang ini, isu atau peristiwa yang dijadikan berita, baik berita politik, hukum, ekonomi, sosial budaya dan entertain disajikan secara aktual dengan menggunakan fakta yang terjadi melalui media massa yang tidak ragu lagi dalam memberitakannya.

\section{Kebebasan Pers}

Karena tidak ada lagi ancaman pencabutan SIUPP ataupun sanksi-sanksi administrasi yang membatasi ruang gerak wartawan. Hal ini menyebabkan kebutuhan masyarakat akan informasi semakin meningkat, sehingga peranan media massa pun semakin meningkatkan kualitas maupun kuantitasnya. Isi media massa di setiap penerbitan selalu mencakup berita dan pendapat.

Kebebasan ini memberikan
kesempatan media massa untuk
menyampaikan informasi, memberikan
bimbingan, mengontrol penyimpangan-
penyimpangan, termasuk mengawasi dan
menyampaikan kebijakan pemerintah.

Keadaan ini merupakan hal yang menguntungkan bagi masyarakat. Namun, kebebasan ini dimanfaatkan oleh sebagian media massa Indonesia untuk mendaparkan keuntungan sebanyak-banyaknya dengan mengabaikan fungsinya untuk mendidik masyarakat. Kebablasan pers ini dapat terlihat pada pemberitaan yang kurang balance antara kepentingan masyarakat dan kepentingan pers.

Saat ini media massa cenderung hanya mempublikasikan dan mementingkan tiga kriteria, yaitu seks, kriminal, dan konflik.

Konflik merupakan salah satu peristiwa yang menarik dan juga daya tarik atau nilai berita. Konflik bagi pers memang mempunyai nilai berita yang tinggi. Konflik yaitu segala sesuatu yang bersifat pertentangan. Konflik menarik untuk diberitakan, arena konflik adalah bagian dari kehidupan manusia.

Pertentangan ini dapat menyangkut orang perorangan, organisasi massa, partai politik, penduduk satu daerah dengan penduduk daerah lain, dan Negara dengan Negara. Masalah pertentangan dapat menyangkut persoalan harga diri, hukum, batas wilayah, ekonomi dan masalah lainnya.

Dalam menyajikan berita di surat kabar, redaksi hanya memberikan fakta tanpa mencampurkan antara pendapat atau opininya terhadap isu peristiwa tersebut.

\section{Tajuk Rencana}

Selain menyajikan berita, surat kabar juga memiliki hak untuk menyampaikan pendapatnya terhadap isu atau peristiwa. Hak tersebut disampaikannya melalui tajuk rencana atau editorial. 
Pada setiap surat kabar, tajuk rencana atau editorial memiliki nama yang berbeda-beda. Editorial tidak lain adalah kata pengantar dari redaksi sebuah media massa seperti surat kabar, majalah atau tabloid.

Meskipun namanya berbeda-beda, namun tujuannya sama, yaitu memberikan komentar, mengemukakan pendapat atau menyampaikan sikap redaksi terhadap suatu isu atau peristiwa yang sedang hangat terjadi di masyarakat.

Dalam editorial biasanya diungkapkan adanya informasi atau masalah aktual, penegasan pentingnya masalah, opini redaksi tentang masalah tersebut, kritik dan saran atas permasalahan dan harapan redaksi kan peran serta pembaca.

Pendapat atau sikap ini pada dasarnya betujuan untuk mengabdi pada peran pers, antara lain menggerakkan dinamika masyarakat, meluaskan cakrawala pandang, menggugah dan meluaskan ruang gerak kreativitas masyarakat serta membangkitkan harapan sehingga masyarakat senantiasa optimis.

Pernyataan fakta dan opini dalam editorial biasanya diutarakan secara singkat, logis, menarik, ditinjau dari segi penulisan dengan tujuan untuk mempengaruhi pendapat, atau menerjemahkan berita yang menonjol agar pembaca menjadi meyimak seberapa berita tersebut. Fungsi editorial adalah menjelaskan berita, arti berita itu, dan akibatnya pada masyarakat. Editorial juga mengisis latar belakang dari kaitan berita tersebut dengan kenyataan sosial dan faktor yang mempengaruhi dengan lebih menyeluruh.

Dalam editorial terkadang juga ada ramalan atau analisis kondisi yang berfungsi untuk mempersiapkan masyarakat akan kemungkinankemungkinan yang dapat terjadi serta meneruskan penilaian moral mengenai berita tersebut. Dari beberapa bahasan tersebut menunjukkan bahwa sebuah editorial penting pada surat kabar tertentu.

Untuk menjadi layak cetak, sebuah editorial harus berdasarkan pengamatan, pengalaman dan penelitian yang sangat hati-hati. Karena reputasi surat kabar bergantung pada bahan-bahan yang digunakan untuk menuliskan editorial. Maka dari itu peneliti ingin membingkai sebuah editorial.

Mengingat pentingnya peran pers tersebut, maka suatu kewajiban bagi redaksi surat kabar untuk memihak pada kebenaran. Makna tajuk rencana atau editorial tidak bisa merupakan kepanjangan lidah redaksi dalam menyuarakan kebenaran kepada masyarakat.

Opini yang dituliskan pihak redaksi diasumsikan dapat mewakili pendapat dan sikap di sebuah penerbitan surat kabar. Editorial juga merupakan suara kolektif seluruh wartawan dan karyawan dari sebuah perusahaan penerbitan pers. Oleh karena itu editorial tidak ditulis dengan mencantumkan nama penulisnya.

Jelas sekali bahwa editorial membawakan pendapat surat kabar dan dukungan modal atau organisasi-organisasi yang ada di belakangan surat kabar itu, penulis editorial yang umumnya adalah pemimpin redaksi atau redaktur senior, haruslah orang-orang yang terpercaya dan mengetahui kebijakan pemberitaan serta kebijakan surat kabar tempat dia bekerja.

Apapun yang dibahas atau diulas, editorial tidak boleh menyampingkan pendapat redaksi sebagai representasi pendapat dan sikap seluruh wartawan serta 
karyawan suatu lembaga penerbitan pers. Dalam kerangka inilah media penerbitan pers harus memenuhi fungsinya sebagai penyalur sekaligus pembentuk pendapat umum secara kreatif, kritis, dinamis dan konstruktif.

\section{Koran Tempo}

Koran Tempo adalah harian umum milik kelompok Tempo Media. Harian ini diterbitkan oleh perusahaan penerbitan PT. Tempo Inti Media, Tbk yang juga menegeluarkan majalah berita mingguan Tempo (juga terbit dalam bahasa Inggris), dan mengelola media online TempoInteraktif.com , serta KoranTempo.com. Selain itu, kelompok Tempo Media juga membangun kantor berita Tempo news room.

Sejarah pendirian harian umum Koran Tempo tidak bisa dipisahkan dari sejarah pembuatan majalah mingguan berita Tempo, yang sudah jauh lebih dulu muncul dan memperoleh pengakuan dalam bidang jurnalistik dari dalam dan luar negeri. Majalah berita mingguan ini dianggap mewakili kebebasan pers di Indonesia dengan tetap menjunjung nilainilai jurnalisme.

Pada 2 April 2001, ketika umur Tempo menginjak 30 tahun, Gunawan Mohamad bersama kelompok Tempo Media, mendirikan harian umum Koran Tempo.

Harian ini bercita-cita mengembalikan identitas koran pada asalnya, baik secara tampilan, maupun pemberitaan. Hal tersebut disebabkan kecenderungan harian yang terbit saat ini, yaitu menjadikan opini dan kutipan penulisnya sebagai teknik promosi.
Kecenderungan menyimpang lainnya adalah judul yang seringkali tidak sesuai dengan berita, dan terkesan menjual tajuk rencana. Alasan awal penerbitan harian Koran Tempo adalah ketidakmampuan majalah mingguan berita Tempo untuk menampung banyak berita menarik

Setelah melihat peluang pasar, terdapat posisi kosong setelah Kompas, yang berada di peringkat pertama. Kehadiran Koran Tempo bertujuan untuk mengembalikan prinsip-prinsip jurnalistik harian yang terabaikan: cepat, lugas, tajam, dan ringkas.

Nama Tempo sengaja digunakan pada Koran Tempo untuk meraih pangsa pasar. Koran Tempo berusaha meraih pembaca yang masih terbuka lebar, bersaing dengan Kompas, Republika, dan Media Indonesia. Hasilnya luar biasa, di Jakarta, Koran Tempo berhasil menjadi peringkat kedua di bawah Kompas.

Editorial Koran Tempo merupakan opini dari redaksi terhadap isu atau peristiwa yang sedang hangat ditengah masyarakat. Editorial Koran Tempo dimuat setiap hari kecuali hari Minggu. Setiap hari pula isu atau peristiwa dari berbagai bidang yang disikapi oleh redaksi Koran Tempo berbeda-beda, mulai dari isu politik, ekonomi, sosial, hukum, pendidikan.

Dalam situs tempointeraktif.com, melihat dan menilik dari sejarah didirikannya Koran Tempo, yang merupakan bagian dari majalah Tempo, peneliti memilih Koran Tempo dikarenakan dibentuk dari orang-orang sipil muda yang jujur dan mau bekerja, serta menginginkan pemerintahan yang bersih.

Dengan bergerak dengan tulisan "tinta" yang mengutamakan kepentingan rakyat bukan berpihak pada kepentingan 
pemerintahan, mereka pun tidak berpolitik. Dapat dilihat bahwa banyak sekali pemberitaan tentang korupsi yang dibahas oleh Koran Tempo dalam perjalanan panjang sejarah seiring pemerintahan Indonesia yang silih berganti.

Dari aspek tersebut, Koran Tempo memiliki pandangan yang tidak sedikit dalam melemahkan pemerintahan yang berhubungan dengan pemberitaan korupsi tersebut.

Dari peristiwa yang sedang hangat diperbincangkan, yaitu konflik pemilihan Kapolri, memicu Koran Tempo untuk menyajikan pemikiran-pemikiran jurnalisme visual melalui tulisan editorial mereka. Dalam editorial-editorialnya, Koran Tempo mengulik siapa dan apa motivasi dari adanya pemilihan tersebut.

Dan dari pihak KPK (Komisi Pemberantasan Korupsi) yang jelas membeberkan seluk beluk Kapolri tersebut, maka diluruskanlah melalui editorial Koran Tempo. Dengan adanya beberapa pemikiran-pemikiran jurnalis dan redaksi dari Koran Tempo, intinya mereka tetap mendukung dan selalu berpihak pada persatuan dan kesatuan NKRI.

\section{Mantan Kapolri}

Keputusan Komisi Hukum Dewan Perwakilan Rakyat mengesahkan Komisaris Jenderal Budi Gunawan sebagai Kepala Kepolisian sangat disesalkan.

Sehari sebelumnya, Kepala Lembaga Pendidikan Polri ini ditetapkan sebagai tersangka kasus dugaan suap dan gratifikasi oleh Komisi Pemberantasan Korupsi (KPK).

Meski mendukung asas praduga tak bersalah, pengangkatan seorang tersangka dugaan korupsi sebagai pemimpin tertinggi aparat penegak hukum adalah tidak lazim dan bisa berbuntut panjang.

Seorang Kapolri dengan beban kasus di pundaknya tidak akan efektif menjalankan tugas. Komitmennya terhadap pemberantasan korupsi, sebagai salah satu tugas utama Polri, pasti dipertanyakan. Belum lagi ancaman munculnya gesekan antara kepolisian dan KPK, seperti terjadi pada tahun 2009, yang biasa disebut perseteruan Cicak vs Buaya.

Setelah Wakil Ketua KPK bambang widjojanto menjadi tersangka kasus sumpah palsu, hanya dalam hitungan hari Ketua KPK Abraham Samad pun akan menyandang predikat serupa.

Samad dibidik dalam kasus pemalsuan dokumen yang melibatkan Feriyani Lim, seorang perempuan asal Pontianak. Lim dituding menggunakan Kartu Keluarga milik Samad di Makasar untuk membuat Paspor dan Kartu Tanda Penduduk.

Rangkaian fakta ini mudah membuat pikiran tersesat. Seolah-olah yang sedang terjadi adalah kriminalisasi berbalas kriminalisasi. Pandangan ini berpendapat, jika ingin persoalan selesai, kedua pihak mesti menghentikan proses penyidikan, misalnya melalui mekanisme pra-peradilan.

Pembatalan proses akan membuat polisi dan KPK kembali ke titik nol. Padahal kasus Budi Gunawan sudah dilacak jauh hari, sedangkan perkara Bambang Widjojanto sebetulnya sudah dicabut lima tahun silam.

Dengan demikian peneliti ingin mengetahui bagaimana pengkerangkaan Koran Tempo terkait editorial mengenai konflik KPK dan Polri diatas. 
Pengkerangkaan ini diteliti berdasarkan teori framing oleh Robert Entman.

\section{Konstruksi Realitas Sosial}

Konsep mengenai konstruksionis ini diperkenalkan oleh seorang sosiolog yang bernama Peter L. Berger. Ia bersama dengan Thomas Luckman banyak menulis suatu karya dan menghasilkan tesis mengenai konstruksi sosial dan realitas.

Menurut Eriyanto, teori Konstruksi Sosial berada diantara teori fakta sosial dan teori definisi sosial. Dalam teori fakta sosial, struktur sosial yang eksislah yang penting. Manusia adalah produk masyarakat.

Tindakan dan persepsi manusia ditentukan oleh struktur yang ada dalam masyarakat. Institusionalisasi, norma, struktur, dan lembaga sosial menentukan individu manusia. Sebaliknya, teori definisi sosial, manusialah yang membentuk masyarakat. Manusia membentuk realitas, menyusun institusi dan norma yang ada (Eriyanto 2002 : 13)

Dua karakteristik penting dari pendekatan konstruksionis yakkni, pendekatan konstruksionis menekankan pada politik pemaknaan dan proses bagaimana seseorang membuat gambaran tentang realitas. Makna bukanlah suatu yan absolut, konsep statik yang ditemukan dalam suatu pesan. Makna adalah suatu proses aktif yang ditafsirkan seseorang dalam suatu pesan.

$$
\text { Pendekatan konstruksionis }
$$
memandang kegiatan komunikasi sebagai proses yang dinamis. Pendekatan konstruksonis memeriksa bagaimana pembentukan pesan dari isi komunikator dan dalam sisi penerima ia memeriksa bagimana konstruksi makna individu ketika menerima pesan.

Kemudian, realitas menurut Berger tidak terbentuk secara ilmiah tetapi dibentuk dan dikonstruksi. Dengan pemahaman ini realitas berbentuk ganda/plural. Setiap individu mempunyai konstruksi yang berbeda-beda atas suatu realitas, berdasarkan pengalaman, preverensi pendidikan dan lingkungan sosial yang dimiliki masing-masing individu (Eriyanto, 2002 : 15).

Berita dalam pandangan konstruksi sosial bukan merupakan fakta yang riil. Berita adalah produk interaksi anatar redaksi dan fakta. Realitas sosial yang ada tidak begitu saja menjadi sebuah berita, tetapi lebih dahulu melalui beberapa proses.

Proses internalisasi dimana wartawan dilanda oleh realitas yang diamati dan diserap dalam kesadarannya. Proses eksternalisasi, dimana dalam proses ini wartawan menceburkan dirinya dalam memaknai realitas. Hasil dari berita adalah produk dari proses interaksi dan dialektika. (Eriyanto, $2002: 17$ )

Tidak berbeda dengan berita, editorial atau tajuk rencana yang merupakan suara redaksi dalam menanggapi sesuatu atau peristiwa. Editorial atau tajuk rencana juga dilihat sebagai konstruksi atas realitas.

\section{Suratkabar}

Pengertian surat kabar menurut Dja'far Asegaf ialah "penerbitan yang berupa lembaran yang berisikan berita-berita, karangan-karangan, dan iklan yang dicetak dan terbit secara periodik dan dijual secara umum" (Asegaf, $183: 140$ ). 
Peneliti memahami surat kabar merupakan suatu bentuk penerbitan pers yang berupa lembaran, mengenai beritaberita, karangan, iklan yang dicetak dan diterbitkan secara tetap dan teratur serta ditujukan untuk khalayak luas atau masyarakat umum.

Sedangkan menurut Kurniawan Junaedhi, dalam Ensiklopedia Pers Indonesia, "Sebutan bagi penerbitan pers yang masuk dalam media massa tercetak berupa lembaran berita media massa tercetak, berupa lembaran berisi beritaberita, karangan-karangan, dan iklan yang terbit secara umum isinya pun actual" (Junaedhi, 1991 : 257).

Selain aktual dan bermakna, berita pun harus menarik perhatian pembaca untuk membaca isi berita, apa yang menarik perhatian pembaca haruslah terdapat dalam sebuah berita. Karena tujuan pembuatan sebuah berita dalam surat kabar harian adalah agar dibaca.

\section{Opini}

Tajuk rencana atau editorial tidak lain adalah kata pengantar dari redaksi sebuah media massa, surat kabar, majalah, atau tabloid.

Kendati untuk menyebutnya tiaptiap media memberi nama yang berbedabeda, semisal : Gerbang, Gapura, Serambi, dan lain sebagainya tetap tujuannya sama yaitu memberikan komentar, mengemukakan pendapat atau menyampaikan sikap redaksi terhadap suatu peristiwa, isu, atau masalah yang terjadi dalam masyarakat. Dalam surat kabar Tempo, tajuk rencana atau editorial bernama "Editorial".

Pendapat atau sikap ini pada dasarnya bertujuan untuk mengabdi pada masyarakat, maka tidak ada pilihan lain bagi redaksi selain untuk memihak pada kebenaran. Menurut Onong U. Efendi, editorial adalah karya tulis yang merupakan pandangan editor terhadap suatu topik (Efendi, 2003 : 134).Sedangkan dalam buku "Editorial Writing”, Dr. Lyle Spencer mendefinisikan editorial sebagai berikut :

"An editorial is a presentation of fact and opinion in concise, logical, pleasingorder for the sake of entertaining, of influence opinion, or of interpretating, significant news in such a way is importance to the average reader will be clear"

Editorial adalah penyajian fakta dan opini yang disusun secara ringkas, logis, dan menyenangkan untuk menghibur, mempengaruhi opini atau menginterpretasikan berita penting sedemikian rupa sehingga yang pentingnya itu menjadi jelas bagi rata-rata pembaca (Efendi, 2003 : 135)

Berdasarkan pengertian mengenai editorial diatas, peneliti beranggapan bahwa editorial merupakan slah satu hasil karya jurnalistik uyang berisikan opini dari redaksi suatu surat kabar terhadap isu atau peristiwa yang disusun berdasarkan faktafakta yang ada, sekaligus bertujuan untuk mengabdi pada masyarakat dengan memberikan solusi atas permasalahan yang tengah terjadi. 
GAMBAR II.1

Proses Konstruksi Sosial Media Massa

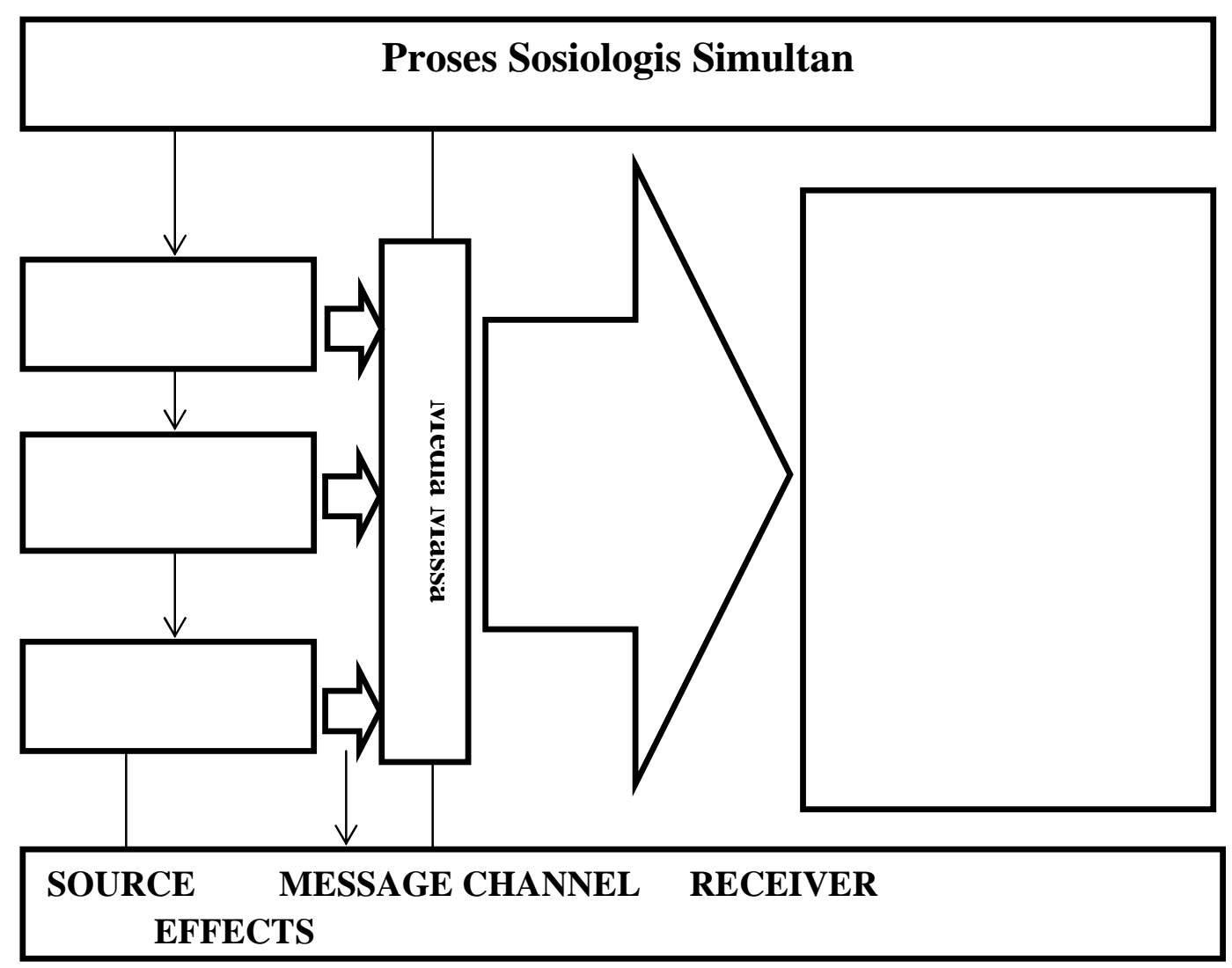


Koran Tempo merupakan surat kabar harian yang turut berpartisipasi meramaikan dunia persuratkabaran di Indonesia.

Berdasarkan penelitian terhadap editorial di Koran Tempo, mengenai konflik KPK dan Polri periode Januari 2015 - 17 Februari 2015, sangat jelas bahwa Koran Tempo dalam menyampaikan opininya terhadap suatu isu atau peristiwa melalui editorialnya bertujuan untuk membela kepentingan masyarakat.

Seringkali dalam editorialnya Koran Tempo memberikan kritikankritikan kepada pihak-pihak yang terkait dalam konflik KPK dan Polri seperti pemerintah, personel KPK, pejabat polisi, dan yang lainnya. Selain itu, Koran Tempo selalu memberikan solusi permasalahan yang berpijak kepada kepentingan masyarakat.

Tajuk rencana pada Koran Tempo bukan hanya membahas tentang konflik KPK dan Polri, tetapi juga memberikan solusi.

Berdasarkan tajuk rencana yang diteliti, mengenai konflik KPK dan Polri selama periode Januari 2015 - 17 Februari 2015, Koran Tempo menunjukkan keberpihakannya kepada kepentingan masyarakat.

Hal ini dapat dilihat pada semua tajuk rencana mengenai konflik KPK dan Polri periode Januari 2015 - 17 Februari 2015 yang telah diteliti menggunakan metode analisis framing Robert Entman, yaitu Problem Identification, yang ditampilkan adalah konflik KPK dan Polri yang dapat menghalangi pemberantasan korupsi. Causal Interpretation, yang ditampilkan ialah KPK dan Polri yang sama-sama memiliki ego lembaga. Moral Evaluation, yang ditampilkan adalah
Jokowi yang tidak pro pemberantasan korupsi. Treatment Recommendation yang ditampilkan adalah Jokowi harus bersikap tegas dan berpihak kepada KPK.

Dari situ dapat terlihat bahwa Koran Tempo mengkonstruksikan sebuah realitas berdasarkan fakta-fakta yang ada. Memang realitas yang ada di masyarakat saat ini menggambarkan ketidakpuasan masyarakat kepada pihak yang terkait mengenai konflik KPK dan Polri yaitu, Pemerintahan dan pejabat polisi.

Namun realitas yang ada tidak begitu saja dimuat dalam tajuk rencana, akan tetapi terlebih dahulu redaksi akan melihat, mempelajari dan menilai realitas tersebut, untuk kemudian hasil penilaian atas realitas tersebut akan dituangkannya kedalam editorial.

Pada saat proses pencurahan ekspresinya, dalam diri redaksi terjadi sebuah proses dialektis dimana redaksi dihadapkan pada aturan, norma dan ideologi yang berlaku, sehingga menyebabkan realitas dikemas sesuai dengan ideologi, aturan dan norma yang ada, bagian mana yang ingin ditonjolkan dan bagian mana yang akan dihilangkan.

Tajuk "Menyelamatkan KPK" ini menyikapi konflik antara KPK dan Polri meliputi adanya Abraham Samad yang akan menyandang predikat serupa dengan Wakil Ketua KPK Bambang Widjojanto dimana ia adalah tersangka kasus sumpah palsu.

Kriminalisasi ini merupakan buntut penetapan Komisaris Jenderal Budi Gunawan sebagai tersangka KPK.

Samad dibidik dalam kasus pemalsuan dokumen, dengan adanya kartu keluarga milik Samad, Feriyani Lim seorang perempuan asal Pontianak menggunakannya untuk membuat paspor 
dan kartu tanda penduduk. Kasus Adnan Pandu Praja dan Zulkarnain yang adalah dua anggota pimpinan KPK juga sebelumnya sudah dilaporkan ke polisi.

Konflik antara kedua pihak ini harus menghentikan proses penyidikan, apabila ingin persoalan selesai, pembatalan proses akan membuat polisi dan KPK kembali ke titik nol.

Menyaksikan gelombang kriminalisasi yang terjadi antara KPK dan Polri ini, Presiden Joko Widodo tak selayaknya berpangku tangan, dan juga agar terhindar dari tudingan akan mengkhianati janji kampanyenya.

\section{Metode Framing Pertama}

Problem Identification. Masalah yang diangkat pada tajuk rencana ini menyeret kasus baru dalam tubuh KPK, yang dalam hitungan hari setelah Wakil Ketua KPK Bambang Widjojanto menjadi tersangka, Ketua KPK Abraham Samad pun akan menyandang predikat serupa.

Selain dari alinea pertama diatas, masalah yang ada dilihat sebagai buntut dari kasus penetapan Komisaris Jenderal Budi Gunawan sebagai tersangka KPK yang disebutkan oleh Koran Tempo dalam alinea ketiga.

Causal Interpretation. Pada bagian ini, Koran Tempo melihat kasus Abraham Samad yang dibidik dalam kasus pemalsuan dokumen yang melibatkan Feriyani Lim sebagai penyebab masalah yang dijelaskan diatas. Sebelumnya juga, dua anggota pimpinan KPK lainnya telah pula dilaporkan ke polisi.

Moral Evaluation. Penilaian atas penyebab masalah ini, bahwa yang terpenting adalah membuat peraturan pemerintah pengganti undang-undang (perpu) yang memastikan pimpinan Komisi mendapat impunitas dari persoalan hukum selama ia masih menjabat. Ini disebutkan dalam alinea kelima.

Treatment Recommendation.

Saran yang diambil oleh Koran Tempo adalah agar adanya pembentukan perpu untuk mengangkat pimpinan KPK sementara menggantikan mereka yang nonaktif dan kasus Budi Gunawan dengan demikian bisa dituntaskan. Ini disebutkan dalam alinea keenam.

Dari penjelasan diatas, tajuk rencana yang ditulis Koran Tempo dan diteliti menggunakan framing Robert Entman, yakni Problem Identification, Causal Interpretation, Moral Evaluation, dan Treatment Recommendation menjelaskan tentang masalah-masalah dari kasus antara konflik KPK dan Polri.

Ini dapat menarik perhatian pembaca menemukan apa yang sebenarnya menjadi pokok permasalahan.

Dengan menemukan pokok masalah tersebut, tajuk ini kemudian memberikan gambaran-gambaran untuk lebih mempermudah pembaca menangkap pesan yang ingin disampaikan oleh Koran Tempo.

Tajuk ini pun ditutup oleh solusi yang merupakan treatment recommendation yang ingin ditawarkan redaksi Koran Tempo terhadap masalah dalam tajuk ini.

Dewan Perwakilan Rakyat yang berupaya untuk memangkas wewenang Komisi Pemberantasan Korupsi justru merupakan tindakan penyerangan terhadap KPK. DPR berusaha menata lagi wewenang KPK dalam hal penyadapan hingga persoalan pembekuan rekening kasus korupsi. Ini sudah terlihat tidak sulit, 
bahwa DPR berusaha melemahkan bahkan melumpuhkan KPK.

Komisi antikorupsi akan sulit membongkar korupsi besar apabila tidak leluasa melakukan penyadapan. Serta usulan politikus Senayan yang menghendaki agar KPK tidak memiliki wewenang lagi dalam hal membekukan rekening.

Lembaga ini akan semakin ditekan dari pihak luar, dan tidak dapat melanjutkan kasus korupsi yang sudah ada.

DPR juga berupaya membentuk lembaga pengawas untuk komisi antikorupsi ini. Ini hanya akan membuat pimpinan KPK bekerja dalam tekanan.

Karena lembaga pengawas juga dapat menyalahgunakan kekuasaan nantinya sebagai intervensi perkara. Dalam hal seperti ini seharusnya DPR dan Pemerintah tidak perlu takut, disini justru terlihat tindakan politikus Senayan ini tidak membantu dalam memerangi korupsi.

\section{Metode Framing Kedua}

Problem Identification. Masalah yang diangkat pada tajuk rencana "Mempreteli Wewenang KPK" ini ditarik Koran Tempo kedalam kutipan di awal alinea, yaitu rancangan anggota DPR yang berupaya memangkas wewenang KPK.

Causal Interpretation. Penyebab masalah dalam tajuk ini adalah DPR yang seolah memanfaatkan kesempatan ditengah kesulitan KPK. Ini terpapar dalam alinea ketiga yang diungkapkan Koran Tempo.

Dari penjelasan diatas, terlihat juga di alinea kedua, DPR melakukan manuver terhadap KPK. Mereka ingin menata lagi wewenang KPK dalam hal penyadapan hingga pembekuan rekening tersangka kasus korupsi.
Moral Evaluation. Bahwa, komisi antikorupsi akan susah membongkar korupsi besar, apalagi melakukan operasi tangkap tangan bila tidak bisa menyadap. Ini dijelaskan Koran Tempo dalam alinea keempat.

Penilaian atas penyebab masalah dalam tajuk ini juga dilihat dari kalimat terakhir pada alinea ketujuh, yaitu tentang keinginan mempreteli senjata utama KPK yang memperlihatkan komitmen mereka yang rendah dalam upaya memerangi korupsi.

Treatment Recommendation.

Dalam hal ini solusi yang ditawarkan Koran Tempo ada pada kalimat pertama dalam alinea terakhir. Apabila tidak terlibat dalam hal-hal yang berhubungan dengan penyalahgunaan wewenang ataupun korupsi, DPR dan Pemerintah pun tidak perlu takut.

Dari penjelasan diatas, tajuk rencana yang ditulis Koran Tempo dan diteliti menggunakan framing Robert Entman, yakni Problem Identification, Causal Interpretation, Moral Evaluation, dan Treatment Recommendation menjelaskan tentang masalah-masalah dari kasus antara konflik KPK dan Polri.

Ini dapat menarik perhatian pembaca menemukan apa yang sebenarnya menjadi pokok permasalahan.

Dengan menemukan pokok masalah tersebut, tajuk ini kemudian memberikan gambaran-gambaran untuk lebih mempermudah pembaca menangkap pesan yang ingin disampaikan oleh Koran Teтро.

Tajuk ini pun ditutup oleh solusi yang merupakan treatment recommendation yang ingin ditawarkan redaksi Koran Tempo terhadap masalah dalam tajuk ini. 


\section{Kesimpulan}

Berdasarkan hasil penelitian ini, peneliti menemukan kesimpulan dari tajuk rencana Koran Tempo dalam kasus konflik KPK dan Polri. Berdasarkan dari peristiwa yang dilihat sebagai apa dan dengan nilai positif atau negatif apa adalah identifikasi masalah konflik KPK dan Polri yang dapat menghalangi pemberantasan korupsi.

Yang menjadi penyebab masalah adalah KPK dan Polri yang sama-sama memiliki ego lembaga. Lalu evaluasi moral atau penilaian atas penyebab masalah tersebut adalah bahwa Jokowi tidak pro pemberantasan korupsi. Sedangkan saran atau penyelesaian masalah yang ditawarkan untuk mengatasi masalah adalah Jokowi harus bersikap tegas dan berpihak kepada KPK.

Dalam tajuk rencana Koran Tempo yang sudah diteliti, bukan hanya konflik yang dipaparkan dan dibahas oleh redaksi, tetapi juga ada solusi yang ditawarkan dan diberikan.

Pada intinya menekankan bahwa Jokowi sebagai Presiden/Kepala Negara harus bersikap tegas dengan membela KPK daripada Polri. Agar Jokowi dilihat publik pro terhadap pemberantasan korupsi. Karena KPK memang dibentuk untuk memberantas korupsi.

\section{DAFTAR PUSTAKA}

Birowo, ed., Metode Penelitian Komunikasi Teori dan Aplikasi (Yogyakarta) Gitanyali, 2004

Elvinaro Ardianto, dkk., Komunikasi Massa Suatu Pengantar (Bandung : Simbiosa

Rekatama Media, 2005,
Eriyanto, Analisis Framing, Konstruksi, Ideologi dan Politik Media,

Soekanto, Soerjono .1982. Sosiologi Suatu Pengantar, (Jakarta : CV Rajawali)

Zenuddin HM, The Journalist Buku Basic Wartawan, Bacaan Wajib Para Wartawan, Editor dan Mahasiswa Jurnalistik (Jakarta : Prestasi Pustakarya, 2007

Sudirman Tebba, Jurnalistik Baru (Ciputat : Kalam Indonesia, 2005M. Antonius Marsen, Martin H, Oxford Leaner's Pokcet Dictionary, (Oxford University, 1999), 
